\title{
Authoritarian resilience and democratic representation in Morocco: Royal interference and political parties' leaderships since the 2016 elections
}

\section{Thierry Desrues}

To cite this article: Thierry Desrues (2020) Authoritarian resilience and democratic representation in Morocco: Royal interference and political parties' leaderships since the 2016 elections, Mediterranean Politics, 25:2, 254-262, DOI: 10.1080/13629395.2018.1543038

To link to this article: https://doi.org/10.1080/13629395.2018.1543038

巴nublished online: 05 Nov 2018.

Submit your article to this journal 4

Џ Article views: 219

Q View related articles $\square$

View Crossmark data ¿

Citing articles: 1 View citing articles 5 


\title{
Authoritarian resilience and democratic representation in Morocco: Royal interference and political parties' leaderships since the 2016 elections
}

\author{
Thierry Desrues (ID
}

Institute of Advanced Social Studies, Spanish National Research Council (IESA-CSIC, JdA), Cordoba, Spain.

\begin{abstract}
After the 'Arab Spring' and the second electoral victory of the Islamist party of Justice and Development in 2016, Moroccan King Mohammed VI had to find new ways to reduce the uncertainty of transparent elections and, as a result, his loss of control over the winner of the House of Representatives elections and the choice of the Head of Government. This profile will analyse a few of the paradoxical implications of the 2011 constitutional reform and the royal narrative for democratic transition, and how these have impacted the political practice of the relevant actors. More precisely, the profile will attempt to clarify the various accommodations by both the King and the political parties, to contextualize the reform and better understand the persistence of authoritarian features despite the democratic hybridization of the Moroccan political system.
\end{abstract}

KEYWORDS Middle East and North Africa; Morocco; political regimes; hybrid regimes; democratic transition; political parties

The King of Morocco, Mohammed Vl, presented the constitutional reform of July 2011 as 'a historic and decisive turning point in the process of completing the construction of the rule of law and democratic institutions'. ${ }^{1}$ To win the support of the main Moroccan political parties, the King had to make two substantial concessions: first, the King would name the head of government from within the party with the largest number of members in the House of Representatives (Article 47) and second, the King would not dismiss the head of government, who is responsible only to his parliamentary majority (Articles 88 and 89 ).

This reform and the issue of its scope refer to the debates on the hybridization of authoritarian political regimes in general and more concretely on the persistence of hybrid regimes (Morlino, 2011). In the wake of the 'Arab Spring' of 2011, Stepan, Linz, and Minoves (2014) insisted on the specificity of monarchical regimes. They proposed a typology that 
distinguishes between three types of regimes: 'ruling monarchy', 'constitutional monarchy' and 'parliamentary democratic monarchy'. Based on the above-mentioned changes, the Moroccan political system would now share two fundamental features of the 'constitutional monarchies' category. In doing so, after the constitutional reform, King Mohammed VI had to look for solutions to the following equation: How to respect the transparency of electoral processes while reducing the uncertainty of their results to govern with parties and a head of government he could trust? In other words, how to prevent an electoral victory of the Islamists of the Party of Justice and Development (PJD) while respecting the letter of the constitution? Until the protest push of 2011, the King was able to impose a series of measures to curb the rise of Islamists: he pressed the PJD to curtail its electoral ambitions; he modified the constituencies in a way favourable to his supporters and, finally, on the eve of the 2009 municipal elections, he approved the creation of the Party of Authenticity and Modernity (PAM) by his friend and Minister Delegate to the Ministry of the Interior, Fouad Ali El Himma.

In the context of the 'Arab Spring', however, this strategy was no longer viable. The King had to find new ways to reduce the uncertainty of transparent elections and, as a result, his loss of control over the winner of the House of Representatives elections and the choice of the head of government. Reasoning from the standpoint of this hypothesis, this profile will demonstrate that the King's control over the choice of a prime minister and ministerial appointments was asserted in the name of his own definition of 'authentic democracy' and by virtue of his constitutional status as Supreme Representative of the nation (Article 42) and as mediator between the institutions (Article 47).

The notion of 'authentic democracy' was coined by the King over successive discourses around the triple obligation for elected officials and administrative staff of responsibility, competence and accountability. For Mohammed $\mathrm{VI}$, the legitimacy of a political party obtained through citizen suffrage is insufficient to justify a call to govern unless it meets a number of conditions before and after the electoral process. Prior to the electoral process, the electorate must remove demagogic purveyors of false promises in favour of candidates who demonstrate competence, credibility and availability to serve the general interest. Voters, therefore, must decide according to the economic and social balance of the candidates. After the elections, the political parties must work for the general interest, which is to say, they must agree independently of electoral results to form an efficient government coalition, appropriate and adapted to the program imposed by royal priorities.

'Authentic democracy' ultimately tries to reconcile two contradictory rationales: the struggle among political parties for democratic access to positions of responsibility and the accountability of policies whose orientations are set by the King. 
This profile does not question the validity of the typology of the monarchical regimes that Stepan et al. (2014) propose, but rather, as they suggest, it attempts to deepen the case studies relating to monarchical regimes. Starting with the Moroccan case, the objective will be to analyse a few of the paradoxical implications of the constitutional reform and the royal narrative for democratic transition and how these have impacted the political practices of relevant actors. More precisely, the profile will attempt to clarify the various accommodations by both the King and the political parties, to contextualize the reform and to better understand the persistence of authoritarian features despite the democratic hybridization of the Moroccan political system. First, the profile will demonstrate that both the 2016 results of the elections to the House of Representatives and the formation of the government which followed show the difficulties encountered in reconciling 'representative democracy' and 'good governance'. It will then describe how this notion of 'authentic democracy' was mobilized to legitimate the imposition of a government more in-line with the wishes of Mohammed VI without departing from the rules set out in the constitution and how this process led to the reconfiguration of the leadership of the main political parties.

\section{The PJD's electoral victory and the conditions of 'authentic democracy'}

When he arrived at the prime minister's office in 2011, A. Benkirane considered that his electoral performance provided a legitimacy that would allow him to coordinate the action of his coalition government and pursue political initiatives in accordance with his Islamist, ideological sensibilities while respecting the royal guidelines. This was not to be. All of the reform initiatives proposed by PJD ministers encountered strong opposition. In most cases, the efforts were abandoned. Despite signs of loyalty communicated by the head of government, Mohammed VI could not bear neither the prime minister's popularity nor the prime minister's criticism of meddling by royal advisers or ministers accountable only to the King. The High Commissioner for Planning, the General Confederation of Moroccan Entrepreneurs, the Moroccan Central Bank and economists published reports which reflected poorly on the government. It was precisely this diagnosis of the PJD's incompetence with respect to ensuring the economic and social development of the country and the execution of the reforms advocated by the King that were used to justify the meddling of royal advisers. Periodic publicity surrounding the dissatisfaction of the two heads of the executive power formalized the contradiction between the emphasized announcement of the head of government's authority and the reality of a King directly implicated in the governance of the country. The paradox reached a climax on the eve of the October 2016 legislative elections. 
PJD activists responded to this situation in May 2016 by extending the mandate of Benkirane as party leader and, moreover, by vetting him as the party's candidate for prime minister. From that date until the October elections, the PJD accused the Ministry of Interior of seeking to discredit the party in favour of parties close to the King. The party was joined in these accusations of a deep state (tahakkoum) seeking to influence electoral outcomes by Hamid Chabat, the leader of Istiqlal, the third political force of the country. In fact, Istiqlal even called for an alliance of the two parties to prevent the return of authoritarianism.

In this unhealthy pre-electoral context, Mohammed VI implicitly declared his preferences. He criticized the conflict between the head of government and those ministers close to him, he faulted the incompetence of the political class and expressed his lack of confidence in elected officials who, according to him, undermined the democratic image of the country. He even summoned those responsible for this situation to remain on the sidelines of the political sphere. Without naming them, he was talking about Benkirane and Chabat.

On 7 October 2016, even though the PJD only received 1.6 million votes out of a possible 15 million votes, his victory upset the Palace. Mohammed $\mathrm{VI}$ acquiesced and appointed Benkirane as head of government. Although Benkirane had won, his majority was far from absolute. He proposed a coalition government with Istiqlal, hoping for far greater autonomy than he had enjoyed in the previous legislature. However, he promptly found himself facing a coalition of parties led by a friend of the King, Aziz Akhannouch. This alliance formed a blocking minority in the parliament and put an end to Benkirane's ambitions by imposing two conditions: first, that the four parties of the coalition be incorporated into any future government and second, that Istiqlal had to be excluded. In his speech of 6 November, Mohammed VI instructed the party leaders on the formation of a new government and confirmed that the Akhannouch coalition was under Palace orders, saying 'Morocco needs a serious and responsible government whose program should not so much meet the ambitions of political parties according to electoral weight as they should cultivate the skills necessary to respond effectively and harmoniously to the program and priorities of the country ${ }^{2}$ as effectively defined by the King himself.

From that point onwards, Benkirane found himself in a situation where he was faced with a suicidal choice: either accept the humiliation of an imposed coalition not accountable to him for his policies or hold his head high and give up on the formation of a government. After 5 months of unsuccessful negotiations, the King revoked Benkirane and nominated instead his rival for the PJD leadership, Saadeddine Othmani. More conciliatory in his approach, Othmani had always presented himself as the PJD's man of the situation, at times when Islamists and the monarchy experienced 
tensions, as they did, for example, following the terrorist attacks of 2003. Othmani responded to the King by forming a government in which the PJD occupied a secondary place despite it being the largest parliamentary group (125 deputies). On the other hand, the ministers of the National Rally of Independents (NRI) (37 deputies), along with those of the Constitutional Union (19 deputies), both members of the King's coalition, were assigned to take charge of the government's economic and development portfolios, including Agriculture, Fisheries, Rural Development, Commerce and Industry, Economy, Finance and Tourism, as well as the Ministry of Justice.

Faced with the electoral victory of the PJD, the King was obliged once again to step in and explain his conditions for accepting the formation of a government. It was in the name of the criteria characterizing what constituted an 'authentic democracy' that he managed the 'tour de force' of honouring the election results and the constitution, while de facto imposing his choices. The performative scope of the King's directives was made possible by constitutional norms and a favourable balance of power. He used his constitutional prerogatives as 'Supreme Representative of the nation' who ensures the functioning of democracy rule (Article 42), the obligation of accountability (Article 1 Paragraph 2), pluralism and arbitration of conflicts between the institutions (Article 47), i.e., between the government and the parties in parliament. Moreover, he benefited from the electoral system that leads systematically to coalition governments and, therefore, reduces the popular appeal of political parties. Finally, Benkirane's refusal for 5 months to yield to the Palace's injunctions highlighted the need for political parties to promote leaders that enjoy the King's confidence. Only with such profiles is Mohammed VI able to ensure, independently of electoral results, the appointment of a conformist head of government and thus of one who would limit himself to relaying the King's policies.

\section{The reconfiguration of the leaderships of the main Moroccan political parties: PJD, RNI and Istiqlal}

Delegates to the PJD congress that took place in December 2017 were faced with an alternative for the election of the general secretary of the party: they could either elect the new head of government, Saadeddine Othmani, and thus show acquiescence to the King's preferences or they could restore Benkirane's leadership, thereby signalling Islamist opposition to Mohammed VI's conception of power. Eventually, delegates opted for the benefits of participating in the government. Ever since, the King has witnessed the division of the party between those who agreed to limit their role to the management of public policies on one hand, and those who claimed certain autonomy and vindicated a 'popular representative democracy' on the other. 
On the eve of election day of October 2016, the fate of the RNI, a party created by the brother-in-law of King Hassan II in 1978 as a home for entrepreneurs and technocrats destined for ministerial appointments, was uncertain. Having ended up only in fourth place, the party's secretary general immediately resigned and Akhannouch was designated as his successor. Obviously, this friend of the King and third wealthiest person of the country, with vested financial interests in many sectors, including hydrocarbons, agribusiness and the media, and a former Minister of Agriculture since 2007, was not elected to stay in parliamentary opposition. After the King's speech defining 'authentic democracy', no one doubted that Akhannouch had been chosen by the Palace to oversee the implementation of royal directives during the formation of the new government. Akhannouch clearly embodies the model of the minister-entrepreneur that Mohammed VI wishes to promote to revive the country's economic development. As Minister of Agriculture he represents the skills and efficiency of a private manager in the service of the public administration. To his detractors, however, Akhannouch personifies the collusion between the monarchy and big business groups in a context of political and economic reforms, thus representing a sort of crony capitalism. As a businessman co-opted by the monarchy since the mid-1990s, the services rendered to the monarchy have caused his fortune to prosper. Also, in parallel with the management of the Ministry of Agriculture, he undertook to upgrade the party structure to be ready to win the next elections.

The Istiqlal which had held the Prime Minister's office from 2007 to 2011 had been swept away by protest movements and the PJD's electoral victory. It was Hamid Chabat, who, by taking advantage of his control over the party's union and his election as mayor of Fez, became secretary general in 2012 at the expense of the family of former prime minister, Abbas el Fassi. During his tenure, Chabat showed that he was incapable of defeating the PJD in a general election. Above all, he was regarded responsible for repeatedly crossing red lines that thwarted the King: in 2013, he provoked the exit of the Istiqlal ministers from the government against the will of the King; in 2016, he questioned the democratic image of the country; and in December of the same year, he made clumsy statements about the Moroccan character of Mauritania at a time when Mohammed VI was preparing Morocco's return to the African Union.

Despite these oddities, he did not feel concerned by the King's criticism of accountability and presented himself for re-election at the head of the party in the fall of 2017. This was not the case of the wealthy regional leaders of the Sahara and the Souss who understood the royal message and, therefore, supported the candidature of Nizar Baraka, a member of the El Fassi family, son-in-law of former prime minister Abbas El Fassi and grandson of Allal El Fassi, founder of the Istiqlal party. Moreover, Baraka is 
a competent technocrat, former Minister Delegate for Economic and General Affairs (2007-2011) and Minister of Economy and Finance (2012-2013), who enjoys the confidence of the King, proved by the fact that he was designated immediately as president of the Social Economic and Environmental Council after the Istiqal ministers exited the government in 2013. Thus, after Baraka's victory in October 2017, Istiqlal has reassured the state's upper echelon and is again available to assume government responsibilities.

The leadership changes that have been described above were aimed at ensuring royal control of serious aspirants to positions of leadership in the government. They were also applied with respect to other political formations concerned by the royal injunction of accountability.

\section{Other attitudes towards the royal injunctions of accountability}

In his throne speech of 31 July 2017, Mohammed VI referred to shortcomings in the implementation of many projects, including those related to the development of Al-Hoceima, the main city in the Rif region that witnessed social protests for months. In passing, he criticized the political parties that failed to take responsibility and preferred to hide behind the King rather than be accountable to the population. On 8 August, Ilyas El Omari, the National Secretary of the Party of Authenticity and Modernity (PAM), who also presides over the Tangier-Tetouan-al-Hoceima region, felt targeted and resigned. This announcement by the right-hand man of Fouad Ali El Himma, the King's close political adviser, confirmed the failure of the PAM, whose first vocation since its creation in 2009 was to defeat the PJD.

The resignation of the leader of PAM was not followed by leaders of other political parties. However, on 25 October 2017, after reading the conclusions of a report of the Court of Auditors that highlighted the delays in launching development programs in the Rif, the King dismissed four ministers and secretaries of state, among them, Nabil Ben Abdallah, the Secretary General of the Party of Progress and Socialism (PPS), and Mohamed Assad, the former Minister of the Interior, who had joined the Popular Movement (MP) presumably to become its head at the next party congress to be held in September 2018. To be able to do this, Mohammed VI invoked once again the constitutional articles on accountability (Article 1, Paragraph 2) and his power to dismiss ministers (Article 47). While Assad renounced his ambition to stand for the presidency of the Popular Movement, in fact to the surprise of many observers, Nabil Ben Abdallah ran for the post of secretary general of the PPS and was re-elected for a third term in May 2018. As he recalled in an interview, he had submitted his candidacy only because it had received no disavowal from the upper echelons of the state. Therefore, the case of the PPS confirms the rule that despite constitutional reform and transparency of electoral competition, the 
King retains, directly or indirectly within the framework of a limited pluralism, his power to promote or put an end to political ambitions within political parties.

\section{Conclusions}

In the space of just over 1 year, and despite unfavourable electoral results, Mohammed $\mathrm{Vl}$ increased his control over the government and the party landscape. The political parties placed at the top of their respective organizations personalities with recognized skills, known for their conciliatory attitudes and good relations with the Palace, while nonconformist and populist leaders have been dismissed as irresponsible. By acting in accordance with the King's preferences, these political parties are in a favourable position to remain in the current government coalition or join future governments.

The objective in this profile was not to analyse if the Palace imposed or suggested one or another of the elected actors, or if there were interest groups within the political formations that anticipated the King's wishes. It was rather to demonstrate the scope of the constitutional concessions made by the Palace and shed light on the terms of expression of the hybridity of the regime and thus how the authoritarian rationale bypasses democratic political representation. The analysis shows that Mohammed VI tried to recover what he conceded in pursuing constitutional reform. Reform, however, pushed him towards innovation, giving birth, in fact, to a particular notion called 'authentic democracy'. This has been all the more effective as political parties continue to fall short of mobilizing public interest and, therefore, compete effectively with the popularity of the King. At the same time, this notion respects the rules of democratic processes and satisfies 'international standards' for neoliberal good governance. In practice, however, this formula is at odds with concealing that the reordering of the Moroccan polity, far from deepening the democratization process, actually reinforces monarchical authoritarianism in its neopatrimonial version and does not put an end to social unrest. Some large demonstrations have recently occurred in several peripheral regions (Jerada, Zagora), and since April 2018 an unknown form of protest appeared in Morocco, i.e., a social media boycott campaign against three big companies. Because 'Afriquia', the petrol station network of the Akhannouch conglomerate 'AKWA Group', is one of those that have been affected by this successful campaign, it can be considered that this protest was a mobilization of public opinion against Morocco's crony capitalism. After all, it remains to be seen whether this is a precursor of further criticism in the future against the pervasive royal control over the current party landscape. 


\section{Notes}

1. The speeches are available at http://www.maroc.ma.

2. Royales speeches, "Full Speech of HM the King on 41st Anniversary of Green March », Ministry of Culture and Communication, maroc.ma, http://www.maroc. ma/en/royal-speeches/full-speech-hm-king-41st-anniversary-green-march.

\section{Disclosure statement}

No potential conflict of interest was reported by the author.

\section{Funding}

This work was supported by the Spanish Ministry of Economy and Competitiveness [grant number CSO2014-52998-C3-2-P], Spanish National Agency for Research, European Regional Development Fund [grant number CSO2017-84949-C3-2-P].

\section{ORCID}

Thierry Desrues (D) http://orcid.org/0000-0002-7097-405X

\section{References}

Morlino, L. (2011). Changes for democracy: Actors, structures, processes. Oxford: Oxford University Press.

Stepan, A., Linz, J. J., \& Minoves, J. F. (2014). Democratic parliamentary monarchies. Journal of Democracy, 2014. 25(2), 35-51. 